\title{
EDITORIAL PROJECT
}

\section{Publishers}

- Director: Elisabeth Gateau, Secretary General, UCLG

- Deputy Director: Alberto Laplaine Guimarãis, Deputy Secretary General, UCLG

- Principal Adviser: Emilia Sáiz, Chief of Staff, Director of Statutory Issues and Institutional Relations, UCLG

- Coordination: Edgardo Bilsky, Director of Programmes and Research, UCLG

- Coordination Assistant: Claire Frost, Project Officer, UCLG

- Support team from UCLG: Dominique Arrestat, Pere Ballester, Mohamed Boussraoui, Jean-Baptiste Buffet, Sandra Climent, Alexis Demko, Sara Hoeflich, Ricardo Martínez, Mónica Mora, Carole Morillon, Thibaut Nancy, Natalène Poisson, Marie-Laure Roa, Maya Sawmy, Elisabeth Silva, Renske Steenbergen

- Interns: Justine Delefortrie, Eugénie Monasterio, Elsa Payan

\section{Steering Committee}

\section{UCLG Regional and Metropolitan Sections}

- Don Borut, Secretary General, UCLG North America

- Jean-Pierre Elong Mbassi, Secretary General, UCLG Africa

- Josep Roig, Secretary General, Metropolis

- Rassikh Sagitov, Secretary General, UCLG Euro-Asia

- Guillermo Tapia, Secretary General, FLACMA, UCLG Latin America

- Frédéric Vallier, Secretary General, Council of European Municipalities and Regions (CEMR), UCLG Europe

- Peter Woods, Secretary General, UCLG Asia Pacific

- Selahattin Yildirim, Former Secretary General, UCLG Middle East \& Western Asia

\section{Experts Coordination}

- Jorge Martínez-Vázquez, Regents Professor of Economics and Director of International Studies, Andrew Young School of Policy Studies, Georgia State University, U.S.A.

- Paul Smoke, Professor of Public Finance and Planning and Director of International Programs, New York University / Robert F. Wagner Graduate School of Public Service, U.S.A. 


\section{Principal Partners}

- William Cobbett, Manager, Cities Alliance

- Àngel Cortadelles i Bacaria, Director General of International Relations, Generalitat de Catalunya, Spain

- Sandrine Delibiot, Director of International Relations and Marketing, Public and Wholesale Banking, Dexia Bank

- Antoni Fogué, President of the Diputación de Barcelona and of the UCLG Committee on Decentralization and Local Self-Government, Spain

- Nathalie Le Denmat, Director of Local Governments and Urban Development, French Development Agency - Agence Française de Développement (AFD), France

\section{Regional Advisers}

- Sandra Ceciarini, Director of Citizenship and International Cooperation, CEMR

- Rudi Hauter, Associate to the Secretary General, UCLG Asia Pacific

- Christopher Hoene, Director of Research, National League of Cities, U.S.A.

- Souleymane Maiga, Chief of Staff, UCLG Africa

- Néstor Vega, Academic Coordinator, FLACMA, UCLG Latin America

- Cenk Tikiz, General Coordinator, UCLG Middle East \& Western Asia 